\title{
INTERACTIVE P\&E METHOD IN TEACHING PHYSICS AT SECONDARY SCHOOLS
}

\author{
Luboš KRIŠŤÁK, Miroslav NĚMEC, Ján STEBILA, Zuzana DANIHELOVÁ
}

\begin{abstract}
The paper deals with the possibilities of using interactive P\&E method with supplementary teaching aid in a form of multimedia DVD in teaching of the topic - nuclear physics at secondary schools in Slovakia. The paper deals also with the interactive P\&E method, whose main idea is interactive working with students with the help of experiment and problem task analyses and with multimedia DVD. DVD contains supplemented study text from nuclear physics for grammar schools, a set of computer aided experiments and problem tasks from nuclear physics. DVD contains also teacher's guidelines and students' worksheets available for each task. The second part of the paper is a pedagogical research aimed at practical verification of use successfulness of multimedia DVD from nuclear physics in real secondary school conditions.
\end{abstract}

Key words: Teaching Physics, nuclear physics, secondary school, multimedia DVD, P\&E, PC.

\section{Introduction}

Key competences of pupils and their development have become more current recently [1]. This fact is a consequence of the Slovak pupils results in international researches; e.g. in a study of OECD PISA (Programme for International Student Assessment) carried out in 2006 aimed at scientific literacy showed that Slovak pupils, in comparison to other OECD countries, achieved significantly lower statistical results than is the average of OECD countries. The research showed that Slovak pupils can describe scientific issues; they are able to select the knowledge and facts appropriately in order to explain the issues and are able to use simple models, but they have problems with hypotheses stating, with experimenting as a tool for data acquisition and their subsequent analysis, interpretation and conclusion formulation $[2,3]$.

\section{State of the Art}

Results of year-long research into teaching Physics are represented by the knowledge and generalisations leading to a significant change of the view on teaching of Physics. Significant are considered mainly the working results of Arnold Arons, prof. Lillian McDermott, D. Hastenes, I. Halloun and other groups building on their results $[4,5,6,7]$. Many teachers of Physics ate primary, secondary schools and universities think that teaching Physics does not have a character of science and depends mainly on so called pedagogical talent of the teacher. However research results of these (and other) groups proved that teaching of Physics can be based on science and methodology of Physics can be understood as a systematic scientific discipline whose procedures and results can be replicated. One of the research results mentioned above is for instance the learning pyramid (Fig. 1), which implies that the most important presumption of the change in teaching Physics is the change in student position to an independently and actively recognising element of the teaching process $[8$, 9].



Fig. 1 Learing Pyramid [10].

Recently this knowledge has become a base for the origin of new approaches and methods used in teaching Physics. Their use brings significantly better results than the use of traditional methods.

Some of other these methods are PI (Peer Instruction), ILD (Interactive Lecture Demonstration), JiTT method (Just-in-timeteaching), etc. $[11,12]$. These methods emerge mainly from the interaction between the lecturer and students, whereas students are actively involved into individual stages of the teaching 
and learning process and actively participate in solving of the dealt problems what gives an immediate feedback to the lecturer and he/she can immediately respond to incorrectly understood concepts, or misconceptions [13].

\section{Interactive P\&E Method}

At the Technical University in Zvolen (Slovakia) we tried to build on the benefits of using multimedia, experiments and qualitative tasks in the teaching of Physics. The result is the interactive P\&E method [14], whose main idea is interactive working with students with the help of experiment and problem tasks analyses and to change the position of student from a passive one to an active one. The method consists in dividing the lesson into 5-10 minute blocks. Within these blocks the teacher (usually) deals with one important physical concept whereas each of these blocks is followed by a problem task that is being dealt by students within a discussion with the presence of the teacher.

Phases of the interactive P\&E method:

1. Preparatory phase: In the case of lesson aimed at explanation the teacher sets basic concepts which he/she wants to explain and deal with in the lesson. He/she prepares a block of 5-10 minutes for each concept. Within this block the concept is being dealt with and the teacher also presents few physical problems connected to the given concept.

2. Dealing with the concept: The teacher teaches the $5-10$ minute block during which he/she deals with the important physical concept (or more concepts).

3. Assignment of a problem: Presentation of a problem task, connected to the dealt concept, follows. Problem task can be, in the case of P\&E method, assigned in for ways:

- task assigned in the form of a text (e.g. How does a ship's draught change after shipping out from a river into the sea?),

- via experiment - teacher performs a simple experiment. To explain this experiment it is necessary to understand the concept dealt with during the previous block (it can be a traditional or computer aided experiment),

- via video-experiment - teacher plays experiment recorded by a video camera [15],

- via applet (simulation) $[16,17]$.
4. Problem solving: After the teacher assigned the problem (in one of the four ways) a class discussion follows. Within the discussion the students, under the teacher's supervision, discuss possible solutions of the given problem. Teacher gradually writes the solutions on the board. Discussion about individual solutions follows; incorrect solutions are excluded following a physical reasoning. This process continues until there is only one correct solution. Students write into their worksheets incorrect solutions including the physical reasoning and also the correct solution. In the next part the teacher explains the connection of the given problem to everyday life and practice and where the students can encounter this, or similar problems. At the end of this part the teachers goes with the students through the questions and tasks assigned in the students' worksheets.

For each way of setting of problem students' worksheets and teachers' guidelines were created. Students get a worksheet for each problem dealt with in a lesson (assigned in any way). Examples of students' worksheets for problems assigned in a form of a text and via experiment:

Structure of students' worksheets for problem assigned in a form of a text

\section{Name of the experiment}

A little bit of theory - the introduction can contain an example from everyday life that motivates pupils to solve the problem raised at the end of this part.

Problem task - assignment of the problem task

Task analysis - a brief analysis of a problem task and its connection to Physics

Possible answers - students under the supervision of the teacher write possible solutions of the problem task

Incorrect answers - students, in stages, write incorrect answers and include physical reasoning why they cannot be correct 
Correct answer - students write the correct solution of the problem task including physical reasoning

Connection to life and practice - in this part pupils learn what practical impact of the given problem is and where, in every day life, they can come across with it or with similar problems

Questions and tasks - additional questions and tasks corresponding to the problem and phenomena closely connected to it

Structure of students' worksheets for problem assigned via traditional experiment [18]

\section{Name of the experiment}

A little bit of theory - the introduction can contain an example from everyday life that motivates pupils to solve the problem raised at the end of this part.

What do we need - list of aids used during the experiment.

Scheme of the experiment - detailed scheme of the experiment development.

How will we proceed - detailed procedure of the experiment.

Problem task - carrying out of experiment and assignment of the problem task

Task analysis - a brief analysis of a problem task and its connection to Physics

Possible answers - students under the supervision of the teacher write possible solutions of the problem task

Incorrect answers - students, in stages, write incorrect answers and include physical reasoning why they cannot be correct

Correct answer - students write the correct solution of the problem task including physical reasoning

Connection to life and practice - in this part pupils learn what practical impact of the given problem is and where, in every day life, they can come across with it or with similar problems.

Questions and tasks - additional questions and tasks corresponding to the problem and phenomena closely connected to it.
In the case of a problem assigned via experiment the problem task can be the solving of experiment. In this case the teacher describes the given experiment and students discuss the solution of the experiment. Teacher carries out the experiment within the analysis of possible solutions proposed by students. In the case of a problem task assigned via video-experiment, the problem task can be the end of the videoexperiments. In such case the whole videoexperiment is played within the discussion about possible solutions or the problem can be represented by the physical essence of the videexperiment. In this case a video-analysis can be played for students within the explanation [19].

\section{Nuclear physics at secondary schools}

The paper is focused on using the interactive P\&E method in the field of nuclear physics presented in the $3^{\text {rd }}$ grade of secondary schools in the Slovak Republic (within the topic "Electromagnetic radiation and the Micro-world of Particles"). Consultations with secondary school teachers revealed that they deal with the topic of nuclear physics within 3-5 lessons on average; within these lessons they deal with following topics:

- Radioactivity

- Alpha, Beta and Gamma Radiation

- Principles of protection against nuclear radiation, Radionuclides in practice

- Atom

- Fission of uranium nuclei, nuclear chain reaction, nuclear power plant,

In spite of the difficulty and excessive abstractness of this area of Physics given chapter does not contain any experiments enabling better understanding of such a difficult issue. One of the possibilities of reducing excessive abstractness and difficulty of the given chapter is the integration of experiments into the chapter. Nuclear physics experiments are a suitable tool for development of scientific literacy of the $3^{\text {rd }}$ grade students; according to mentioned study of PISA, scientific literacy belongs to key competences. Experiments can increase demonstration of physical phenomena being dealt with on a lesson. Moreover, experiment can increase students' interest in Physics, motivate them to increased activity and contribute to the development of creative skills [20]. Using of experiments prepares the pupils for solving of tasks which they can later encounter in everyday 
life $[21,22]$. Creative experiments integrated into the teaching process increases the level of understanding and attention of students and at the same time the theory of physics is becoming interconnected with everyday life [23, 24, 25].

While Slovak secondary schools have not experienced such experiments by now, in other countries they are a common part of the teaching process (Tab. 1).

Tab. 1 Comparison of using experiments in teaching of nuclear physics at primary schools in Slovakia and other countries

\begin{tabular}{|c|c|c|}
\hline & $\begin{array}{c}\text { Number of } \\
\text { experiments }\end{array}$ & Way of carrying out \\
\hline Slovakia & 0 & - \\
\hline England & 7 & $\begin{array}{c}\text { Pupils experiments, } \\
\text { simulations, applets }\end{array}$ \\
\hline Austria & 7 & $\begin{array}{c}\text { Pupils experiments, } \\
\text { demonstration } \\
\text { experiments, applets }\end{array}$ \\
\hline Germany & 7 & $\begin{array}{c}\text { Pupils experiments, } \\
\text { demonstration } \\
\text { experiments, applets }\end{array}$ \\
\hline Poland & 5 & Simulations, applets \\
\hline USA & 8 & Simulations, applets \\
\hline
\end{tabular}

\section{Multimedia DVD from Nuclear Physics}

Physics and Technology are often considered difficult subjects. Mainly it is due to the fact that it is not easy to explain empirical principles and dynamic phenomena in text books. Multimedia technologies showed their potential in teaching such subjects. New techniques increase pupil's attention - it enables easier and faster learning. Pupils like to work with computers and modern information technologies [26]. If we connect working with computer with the study of Physics such form will be very interesting for pupils and it can be supposed that they will achieve better study results [27]. It can be supposed that multimedia support can increase the effectiveness of physical education at secondary schools [28].

We created a multimedia DVD from nuclear Physics. The aim, during its creation, was to introduce elements of a real laboratory into teaching of scientific and technical subjects [29]. The attention was paid to the area of nuclear Physics at primary schools as this topic does not contain any experiments and it is dealt only in theory.

The contents of the multimedia DVD is divided into three main parts:
1) First part is theoretical, i.e. elaborated curriculum from nuclear Physics. During the curriculum elaboration we considered the analysis of Slovak and foreign textbooks and created a textbook that is, in comparison to Physics textbooks for the $3^{\text {th }}$ grade of secondary schools, enlarged and changed for the needs of experiments integration into teaching of this topic. As today's curriculum in textbooks of scientific subjects is being said to be excessive, we tried not to introduce new concepts. Introduction of new concepts was only due to experiments integration. The topic was enlarged only to a minimal extent so that the number of lessons needed could remain the same. Mentioned changes were carried out only in chapters that enabled integration of practical experiments. Text is divided into $5-10$ minute blocks for a eventual use of the interactive $\mathrm{P} \& \mathrm{E}$ method.

2) Second part deals with experiments. It was necessary to create an accompanying text to the experiments for teachers and students to enable them as effective carrying out of experiments as possible. Therefore, this part is divided into three parts: guidelines for teachers, worksheets for students and videos. Individual stages of experiments were selected in order to develop, beside practical skills, also creativity. This part includes 9 experiments altogether: measuring of atmospheric radioactivity, absorption of beta radiation, range of alpha particles in the air, statistics of radioactive decay, half life of radioactive emitter, measuring by means of a ionisation chamber, absorption of radioactivity by means of different materials and gamma ray absorption measurements.

3) Third part of the multimedia DVD consists of problem tasks from nuclear Physics elaborated in the style of PISA tasks; their aim is to verify students' understanding of the topic. Problem tasks are selected in a way to enable the teacher the use the interactive $\mathrm{P} \& \mathrm{E}$ method for the teaching of nuclear physics, i.e. to enable to divide the curriculum into 5 - 10 minute blocks and to have enough problem tasks for each physical concept. The majority of problem tasks is assigned in the form of a text, some via experiment and some via applet. Teachers' guidelines and students' worksheet is available for each problem task. 


\section{Pedagogical Research Research Object}

Students in the $3^{\text {rd }}$ grade of secondary school were the object of the research. Interactive method P\&E with supplementary teaching aid in a form of multimedia DVD from nuclear Physics was used in the teaching of the topic devoted to nuclear Physics.

In control groups the teaching process was carried out in a traditional way, i.e. no experiments were carried out during teaching of the topic. In experimental groups interactive teaching method P\&E was used, moreover the teacher used demonstration within the explanation and student experiments from nuclear Physics were carried out. 5 experiments were carried out altogether within the explanation; some were demonstration some student experiments; there were three demonstration experiments and two applets used within problem tasks. While doing demonstration experiments one set was used; experiment was demonstrated by the teacher with the help of pupils. During pupil experiments three measuring sets were used whereby pupils were divided into three groups.

Regarding experiments and problem tasks after each $5-10$ minute block in experimental groups pupils got worksheets and teachers were provided with teacher guidelines. Worksheets were provided during student experiments as well as during demonstration experiments and problem task solving.

\section{Research Objectives}

The main objective was to verify the effectiveness of the teaching via interactive $P \& E$ method using the multimedia DVD from nuclear Physics in real conditions of selected secondary schools in the subject Physics. Knowledge at the three levels of learning (remembering, understanding, specific and nonspecific transfer use knowledge in typical and problem situations) and active learning of pupils were researched.

To reach the aim partial tasks were determined:

- to verify stated hypotheses using research tools and methods;

- to find out whether the use of multimedia DVD from nuclear Physics influences the level of knowledge of the $3^{\text {rd }}$ grade students at primary school in the subject Physics.

\section{Research Hypotheses}

Based on the aforementioned objective the main hypothesis was formulated:

$\mathrm{H}$ : The use of interactive $\mathrm{P} \& \mathrm{E}$ method with multimedia DVD from nuclear Physics in the teaching of Physics in the $3^{\text {rd }}$ grade of secondary school influences the level of students' knowledge from nuclear Physics from the point of view of statistical significance.

To verify the main hypothesis operational hypotheses were stated:

$\mathrm{H}_{1}$ : At the end of the experimental teaching process students taught by interactive P\&E method and with use of the multimedia DVD achieve higher performance in didactic test in the area of specific and nonspecific transfer than students taught traditionally.

$\mathrm{H}_{2}$ : At the end of the experimental teaching process students taught by interactive $\mathrm{P} \& \mathrm{E}$ method and with use of the multimedia achieve higher performance in didactic test in the area of remembering than students taught traditionally.

$\mathrm{H}_{3}$ : At the end of the experimental teaching process students taught by interactive $P \& E$ method and with use of the multimedia DVD achieve higher performance in didactic test in the area of understanding than students taught traditionally.

$\mathrm{H}_{4}$ : Students in experimental group, where the interactive method P\&E method and multimedia DVD from nuclear Physics is used, will learn more actively during lessons than students in control groups, where multimedia DVD from nuclear Physics is not used.

\section{Research Methods and Techniques}

To achieve the stated objectives and to verify hypotheses following research methods and techniques of empirical research were proposed:

- pedagogical experiment

- didactic test (DT) for verifying operational hypotheses $\mathrm{H}_{1}-\mathrm{H}_{3}$

- standardised questionnaire AUS [30] for verifying hypothesis $\mathrm{H}_{4}$ [31]

- statistical methods for research results processing.

\section{Selection of Respondents}

Groups were selected according to the level of knowledge from Physics characterised by the mark from Physics at the end of the $2^{\text {nd }}$ grade at secondary school and the terminal mark in the $3^{\text {rd }}$ 
grade at secondary school. 10 groups were selected altogether (Tab. 2).

Tab. 2 Structure of individual control and experimental groups

\begin{tabular}{|l|l|l|}
\hline School Name & $\begin{array}{l}\text { Control } \\
\text { group }\end{array}$ & $\begin{array}{l}\text { Experimental } \\
\text { group }\end{array}$ \\
\hline Grammar School I & 34 & 36 \\
\hline Grammar School II & 25 & 26 \\
\hline Grammar School III & 25 & 25 \\
\hline TOGETHER & 84 & 87 \\
\hline
\end{tabular}

The research was carried out on 171 pupils; 84 were in 4 control groups and 87 were in 4 experimental groups. After the selection of suitable groups the pedagogical experiment followed simultaneously during one year in all groups. In all control groups the same curriculum was dealt with. In experimental groups the same curriculum (supplemented minimally for the needs of experiments and divided into $5-10$ minute blocks) was taught via interactive $\mathrm{P} \& \mathrm{E}$ method and experiments were carried out, while the teaching in control groups was carried out traditionally, i.e. without the use of the interactive P\&E method and interactive DVD from nuclear physics.

During the experiment pupils did not know that they were a part of an experiment. After the experiment pupils in all groups took didactic test. All pupils had the same didactic test (there were only two groups that were different in the order of tasks) containing 10 questions. Questions were selected after an agreement with teachers. The majority of questions were open, some were multiple choice. Pupils had 40 minutes to do the test and could reach a maximum of 25 points. The correct answer was evaluated with 1-3 points, according to the level of difficulty. After the test pupils had to fill in the questionnaire; the questionnaire was anonymous and pupils had 10 minutes to fill it in. The aim of the questionnaire was to find out the activity of pupils during teaching and learning process. After the pedagogical experiment obtained data was collected and statistically and qualitatively analysed.

\section{Research Results}

To verify hypotheses $\mathrm{H}_{1}-\mathrm{H}_{3}$ a nonstandardised didactic test - posttest, taken by pupils after dealing with the topic devoted to nuclear Physics, was used.

Normal distribution was verified via Kolmogorov-Smirnov Test. Results in the chart
(Fig. 2) show that there is a difference between knowledge of students in experimental and control group showed in the test. Statistical verification of hypothesis was carried out using two-sample T-test and F-test. At first F-test was used to assess the equality of variances. Following, the hypothesis of equally acquired score in the control and experimental groups was tested. Independent two-sample Student T-test for unequally large populations and equal variances was used [32].



Figure 2 Test successfulness histogram in the control and experimental group. (control group: $\mathrm{N}=\mathbf{8 4}$, Mean $=50.4 \%$, Stand. Dev. $=$ $16.47 \%$, Max $=96 \%$, Min $=10 \%$, experimental group: $\mathbf{N}=87$, Mean $=65.01 \%$, Stand. Dev. 16.74\%, $\operatorname{Max}=98 \%, \operatorname{Min}=20 \%$ ).

\section{Summary of Research Results}

Validity of operational hypotheses is summarised in following table (Tab. 3).

Tab. 3 Summary of individual hypotheses verification

\begin{tabular}{|c|c|c|c|}
\hline $\begin{array}{c}\text { Hypothe } \\
\text { sis }\end{array}$ & $\begin{array}{c}\text { Method of } \\
\text { data } \\
\text { acquisitio } \\
\text { n }\end{array}$ & $\begin{array}{c}\text { Hypothe } \\
\text { sis } \\
\text { validity }\end{array}$ & $\begin{array}{c}\text { Researche } \\
\text { d value }\end{array}$ \\
\hline $\mathrm{H}_{1}$ & $\begin{array}{c}\text { DT - } \\
\text { posttest }\end{array}$ & valid & Application \\
\hline $\mathrm{H}_{2}$ & $\begin{array}{c}\text { DT - } \\
\text { posttest }\end{array}$ & valid & $\begin{array}{c}\text { Rememberi } \\
\text { ng }\end{array}$ \\
\hline $\mathrm{H}_{3}$ & $\begin{array}{c}\text { DT - } \\
\text { posttest }\end{array}$ & valid & $\begin{array}{c}\text { Understand } \\
\text { ing }\end{array}$ \\
\hline $\mathrm{H}_{4}$ & $\begin{array}{c}\text { Standardis } \\
\text { ed } \\
\text { questionna } \\
\text { ire }\end{array}$ & Valid & $\begin{array}{c}\text { Active } \\
\text { learning }\end{array}$ \\
\hline
\end{tabular}

From statistical analyses and results of partial hypotheses testing it is possible to say that the initial hypothesis is confirmed and true. Research into the use of presented multimedia DVD from nuclear physics shows that: 
- Pupils taught by the interactive P\&E method and with the multimedia DVD from nuclear Physics achieved higher performance in the didactic test in the area of specific and nonspecific transfer, understanding and remembering at the end of the experimental education than pupils taught traditionally.

- Pupils taught by the interactive P\&E method and with the multimedia DVD from nuclear Physics learned more actively during lessons than pupils taught traditionally.

\section{Conclusions}

Results obtained during pedagogical experiment, evaluation of didactic tests and questionnaires and after consultations with teachers can be concluded into following points:

1) The use of interactive $P \& E$ method and multimedia DVD from nuclear physics in the teaching process contributes to achieving of higher performance of pupils in experimental groups in the area of specific and nonspecific transfer, understanding and remembering in the given topic. The use of interactive $\mathrm{P} \& \mathrm{E}$ method and multimedia DVD from nuclear physics in the teaching process contributes to increasing of the principle of the curriculum demonstration, includes pupils into all stages of the teaching and learning process thus encourages active working. Pupil experiments develop their ability to work independently. Some experiments were demonstration experiments carried out by the teacher; some were pupil experiment carried out by pupils in groups. During all types of experiment and problem tasks pupils were provided with worksheet which helped them to carry out the experiment (teachers were provided with teacher's guidelines). Worksheets contained plenty of questions a task to think about what forced the pupils to work independently and to look for appropriate solutions.

2) Questionnaire results have shown that experiments from nuclear Physics increase the popularity and attractiveness of the subject Physics. Questionnaire and also talks with pupils have indicated that pupils liked nuclear Physics experiments very much; after the topic of nuclear Physics they evaluated the subject as more interesting, more understandable, more popular and attractive subject.

\section{References}

[1] DEMKANIN, P., PIŠÚT, J., VELMOVSKÁ, $\mathrm{K}$. Vybrané faktory prispievajúce k rozvoju kompetencií žiakov při vyučovaní fyziky, Knižničné a edičné centrum FMFI UK, 2011.

[2] KRUPOVÁ, I. The Development of Natural Science Literacy in Pupils in the First Stage of Basic School Using the Method of Managed Discovery. Pedagogika, Vol. LIX - 2009, No. 3, pp. 259-268. ISSN 0031-3815.

[3] HOCKICKO, P. Nontraditional Approach to Studying Science and Technology. Communications, Vol. 12, No. 3, 2010, pp. 6671. ISSN 1335-4205.

[4] MCDERMOTT, L.C Oersted medal lecture 2001: Physics Education Research - The Key to Student Learning, In: Am.J.Phys., 69(2001), p. 1127-1137.

[5] ARONS, A.B. Achieving Scientific Literacy, In: Daedalus, Spring, 1983 (český preklad: Cesta k př́rodovědní gramotnosti I, II, In: Čs. čas. fyz. A35 (1985), s. 58-68, s. 151-158)

[6] ARONS, A.B. Teaching Introductory Physics, A guide to Teaching for Learning and Understanding. New York: John Wiley and Sons, 1997.

[7] HALLOUN, I., HESTENES, D. „The initial knowledge state of college physics students“, Am. J. Phys. 53 (1985), 1043-1055.

[8] REDISH, E.F. Teaching Physics, John Wiley and Sons, New York, 2003.

[9] HANČ, J., DEGRO, J., JEŠKOVÁ, Z., KIREŠ, M., ONDEROVÁ, L., ČUKANOVÁ, E., KONKOLOVÁ, M. „Rozumejú alebo memorujú vaši žiaci fyziku, ktorú učíte? Štandardizované konceptuálne a postojové testy ako nástroje hodnotenia výučby“. DIDFYZ 2006, Nitra 2007. [10] HANČ, J., DEGRO, J., JEŠKOVÁ, Z., KIREŠ, M., ONDEROVÁ, L'., ČUKANOVÁ, E., KONKOLOVÁ, M., TÓTH, J. Štandardizované konceptuálne a postojové testy vo fyzikálnom vzdelávaní, elektronický preprint, Prírodovedecká fakulta, UPJŠ v Košiciach, 2008.

[11] MAZUR, E. Peer instruction. A user's manual. Prentice Hall, New York, 1997.

[12] CROUCH, C.H., MAZUR, E. Peer Instruction: Ten Years of Experience and ResultsL Am. J. Phys. 69(9), 2001

[13] SOKOLOFF, D.R., THORTON, R.K. Using interactive lecture demonstrations to create an active learning environment" Phys. Teach. 35(6). 1997

[14] KRIŠŤÁK, L', NĚMEC, M. Fyzikálne vzdelávanie na TU vo Zvolene. Vedecká 
monografia. TU Zvolen 2011. ISBN 978-80-2282216.

[15] BROWN, D., COX, A.J. Innovative Use sof Video Analysis", in The Physics Teacher, vol. 47, no. 3, pp. 145-150, 2009, ISSN 0031-921X.

[16] PERKINS, K., ADAMS, W., DUBSON, M., FINKELSTEIN, N., REID, S., WIEMAN, C., LEMASTER, R. „PhET: Interactive Simulations for Teaching and Learning Physics", Physics Teacher, vol. 44, pp. 18 - 23, 2006, ISSN 0031-921X.

[17] WIEMAN, C., ADAMS, W., LOEBLEIN, P., PERKINS, K Teaching physics using PhET simulations, The Physics Teacher, vol. 48, is. 4, pp. 225-227, ISSN 0031-921X.

[18] HOLEC, S. et al. Integrovaná prírodoveda v experimentoch. Žiacke pracovné listy. Banská Bystrica: Fakulta prírodných vied UMB, Medzinárodný projekt Leonardo da Vinci II $\mathrm{N}^{\circ}$. SI 143008 Computerised Laboratory in Science and Technology Teaching, 2004. 126 s. ISBN 808055-903-1.

[19] HOCKICKO, P. Forming of Physical Knowledge in Engineering Education with the Aim to Make Physics More Attractive. In: Proceedings SEFI - PTEE 2011 (Physics Teaching in Engineering Education), Mannheim, Germany (2011), ISBN 978-3-931569-18-1

[20] BEDNAŘÍK, M., LEPIL, O. Netradiční typy fyzikálních úloh, Praxe učitele matematiky, fyziky, informatiky, Praha 1995.

[21] VELMOVSKÁ, K. Rozvíjanie tvorivosti žiakov gymnázia pomocou úloh, Zborník zo seminára, Bratislava: UK, 2001, s. 75-78.

[22] ZELENICKÝ, L. Úloha fyzikálneho experimentu vo vyučovaní. In: MEDACTA'91 čast' 3. Nitra: Pedagogická fakulta, 1991

[23] NACHTIGALL, D.K. What is wrong with physics teachers'education? Eur. J. Phys. 11(1990) 1-14.

[24] BUSSEI, PAOLO AND MERLINO, SILVIA European workshop on Multimedia in Physics Teaching and Learning. Europhysics News, 34(3), 2003, pp. 116-117. ISSN 05317479 .

[25] DYKSTRA, D.I., BOYLE C.F., MONARCH, I.A. Studying conceptual Change in learning physics, Science Education, 1992 (6), pp. $615-652$.

[26] STEBILA, J. Research and Prediction of the Application of Multimedia Teaching Aid in
Teaching Technical Education on the 2nd Level of Primary Schools. Informatics in Education, Vol. 10, No. 1, pp. 105 - 122. ISSN 1648-5831. [27] STURM, B. Science in School, Issue 13, Autumn, 2009,29.

[28] ŽÁČOK, L'. Research examination of the options to increase the education effectiveness in the technical subjects at the 7th grade of elementary school using hypertext educational material. In: Informatics in Education, 9(2), 2010, 283-299. ISSN 1648-5831.

[29] SHELLY, G.B., CASHMAN, T.J., GUNTER, R.E., GUNTER, G.A. Teachers Discovering Computers: Integrating Technology in the Classroom, Thomson Learning, Cambridge, MA, 2001.

[30] KÖBÖLOVA, E., RÖTLING, G., SIHELSKY, B. Príručka na uskutočnenie pedagogického prieskumu. MPC Banská Bystrica. 2006. 80-8041-490-4. (available in http://mpcskolenie1.webnode.sk/studijnematerialy/, studijny material V-PK.doc).

[31] STEBILA, J. Výsledky z výskumu použitia multimediálnej učebnej pomôcky $\mathrm{v}$ reálnych podmienkach základných škôl v SR. Journal of Technology and Information Eucation, 1/2009, Volume 1, Issue 1, ISSN 1803-537X.

[32] KRIŠŤÁK, L., NĚMEC, M. Innovation of physical education at Technical University in Zvolen. Journal of Technology and Information Eucation, 2/2010, Volume 2, Issue 2, ISSN 1803$537 \mathrm{X}$.

\section{PaedDr. L'uboš Krišt’ák, PhD. ${ }^{1}$ \\ Mgr. Miroslav Němec, PhD. ${ }^{1}$ \\ Mgr. Zuzana Danihelová ${ }^{2}$ \\ ${ }^{1}$ Katedra fyziky, elektrotechniky a aplikovanej mechaniky \\ Drevárska fakulta \\ ${ }^{2}$ Ústav cudzích jazykov \\ Technická Univerzita Zvolen \\ T.G. Masaryka 24 \\ 96053 Zvolen}

PaedDr. Ján Stebila, PhD.

Katedra techniky a technológií

Fakulta porodných vied

Univerzita Mateja Bela

Tajovského 40

97401 Banská Bystrica 